\title{
Pengaruh Promosi, Kualitas Pelayanan, Dan Motivasi Terhadap Keputusan Memilih Produk Tabungan Emas di Pegadaian Syari'ah
}

\author{
Aulia Hidayah ${ }^{1 *}$ Hilal Malarangan ${ }^{2}$, Fatma Fatma $^{3}$ \\ ${ }^{1}$ Jurusan Ekonomi Syariah, Fakultas Ekonomi dan Bisnis Islam, IAIN Palu \\ ${ }^{2}$ Jurusan Ekonomi Syariah, Fakultas Ekonomi dan Bisnis Islam, IAIN Palu, \\ ${ }^{3}$ Jurusan Ekonomi Syariah, Fakultas Ekonomi dan Bisnis Islam, IAIN Palu
}

ABSTRAK

Pada penelitian ini ditujukan untuk menguji pengaruh promosi, kualitas pelayanan, dan motivasi terhadap keputusan memilih produk tabungan emas di pegadaian syariah. Sampel penelitian ini adalah nasabah tabungan emas di pegadaian syariah cabang palu plaza.Penelitian ini adalah penelitian lapangan menggunakan pendekatan kuantitatif, teknik pengumpulan data melalui observasi, angket/kuesioner dokumentasi, dan studi pustaka dengan jumlah sampel sebanyak 92 sampel. Tekni pengambilan sampel yang digunakan adalah Analisis Regresi Berganda. Analisis data akan dilakukan setelah mentabulasi data kemudian melakukan uji validitas dan realibilitas lalu dilanjutkan dengan mengolah data menggunakan aplikasi SPSS versi 16.Berdasarkan hasil penelitian dan pembahasan, sesuai dengan rumusan masalah dapat disimpulkan bahwa kualitas Pelayanan berpengaruh positif signifikan terhadap keputusan memilih produk, sedangkan promosi dan motivasi tidak berpengaruh signifikan terhadap keputusan memilih produk.Dari Kesimpulan diatas disarankan, pegadaianharuslah memberikan informasi yang sangatjelas dan mudah dipahami oleh nasabah serta perlu adanya rasa perhatian yang bersifat Individual oleh pegawai kepada nasabah ketika melakukan promosi baik secara langsung maupun dalam bentuk media/brosur.
INFORMASI ARTIKEL

\author{
Katakunci: \\ Promosi, Kualitas \\ Pelayanan, Motivasi, \\ Tabungan Emas
}




\section{PENDAHULUAN}

Pada masa kemerdekaan, berdasarkan Peraturan Pemerintah Nomor 178 tahun 1961, status lembaga pegadaian adalah jawatan pegadaian. Kemudian dengan Peraturan Pemerintah Nomor 10 tahun 1990 tanggal 10 April 1990, perusahaan Jawatan Pegadaian diubah manjadi Perusahaan Umum (PERUM) Pegadaian. Terbitnya Peraturan Pemerintah Nomor 10 Tahun 1990 tanggal 1 April 1990 dapat dikatakan menjadi tonggak awal kebangkitan Pegadaian.

Satu hal yang perlu dicermati bahwa Peraturan Pemerintah Nomor 10 Tahun 1990 menegaskan misi yang harus diemban oleh Pegadaian untuk mencegah praktik riba, di mana misi ini tidak berubah hingga terbitnya PP.No.103 tahun 2000 yang dijadikan landasan kegiatan usaha Perum Pegadaian sampai sekarang. Setelah melalui kajian yang panjang, akhirnya disusunlah suatu konsep pendirian unit Layanan Gadai Syariah sebagai langkah awal pembentukan divisi khusus yang menangani kegiatan usaha syariah $^{1}$

Sistem ekonomi Islam mulai disepakatioleh pemerintah ditandai dengan berdirinya usaha-usaha yang berbasis syariah seperti bank syariah pasar modal syariahserta aktivitas ekonomi syariah lainnya yang

\footnotetext{
${ }^{1}$ Martono, Bank dan Lembaga Keuangan Lain. (Yogyakarta: EKONISIA, 2004), h.168
}

berkembang akhir ini Diantaranya adalah pegadaian syariah. ${ }^{2}$ Keberadaan pegadaian syariah sangat dibutuhan oleh masyarakat kelompok ekonomi lemah yang sangat rasional untuk memanfaatkan jasa pegadaian syariah apabila memberikan kemudian dalam barang jaminan, cepat dan mudah sehinggamereka merasa tertolong sehingga keberadaan pegadaian syariah sebagai rahmatan lil'alamin akan terasakan.

Dalam pegadaian syariah atau rahn terdapat beberapa istilah jadi orang yang menyerahkan barang gadai disebut rahin orang yang menerima barang gadai disebut murtahin dan barang yang digadaikan yaitu marhun. ${ }^{3}$ Produk-produk pegadaian syari'ah bermacam-macam disediakan untuk masyarakat misalnya Ar-Rahn, Mulia, pembiayaan, krista dan lain sebagainya. Produk-produk berbasis syariah memiliki karakterisitik menetapkan uang sebagai alat tukar bukan sebagai komoditas yang diperdagangkan. ${ }^{4}$

Berdasarkan Pasal 92 Undangundang Nomor 19 Tahun 2003 Tentang BUMN, dikeluarkanlah Peraturan Pemerintah Nomor 51 Tahun 2011 Tentang

\footnotetext{
${ }^{2}$ Heri Sudarsono, Bank dan Lembaga Keuangan Syariah;Deskripsi dan Ilustrasi (Yogyakarta: Ekonisia,2003),h. 158

${ }^{3}$ Buchari Alma, Manajemen Bisnis Syariah (Cet: I; Bandung: Alfabeta,2009), h.30

${ }^{4}$ Abdul Ghofur Anshari, Gadai Syariah di Indonesia, (Jakarta: Gajah Mada Univesity Press, Tahun 2006), h.47
} 
Perubahan Bentuk Badan Hukum Perum menjadi PT. Pegadaian (Persero). Perubahan Perum menjadi PT. Pegadaian (Persero) sebagaimana terdapat dalam Peraturan Pemerintah Nomor 51 Tahun 2011 Tentang Perubahan Bentuk Badan Hukum Perum menjadi PT. Pegadaian (Persero) adalah dalam rangka lebih meningkatkan efisiensi dan efektivitas penyelenggaraan penyaluran pinjaman khususnya masyarakat menengah kebawah, usaha mikro, usaha kecil, dan menengah. ${ }^{5}$

Kegiatan gadai syariah merupakan suatu gejala ekonomi yang baru lahir semenjak regulasi Undang-Undang Nomor 7 Tahun 1992, Undang-Undang Nomor 10 Tahun 1998, Undang-Undang Nomor 21 Tahun 2008 Tentang Per bankan Syariah. Regulasi ini direspon oleh Dewan Syariah Nasional dengan mengeluarkan Fatwa Nomor 25/DSN-MUI/III/2002 Tentang Rahn dan juga Fatwa Nomor 26/DSNMUI/III/2002 Tentang Rahn Emas. ${ }^{6}$ Hadirnya Pegadaian Syariah Cabang Palu Plaza ditengah masyarakat Kota Palu

\footnotetext{
${ }^{5}$ Julianty M Paputungan, "Akibat Hukum Perubahan Status Perusahaan Umum (Perum) Menjadi Perseroan Terbatas PT. Pegadaian (Persero)', Jurnal, Fakultas Hukum Program Pascasarjana (S2) Universitas Hasanuddin Makassar,Vol III, No. 2, 28 Februari 2019, h. 3

${ }^{6}$ Ahmad Supriyadi, "Struktur Hukum Pegadaian Syariah Dalam Perspektif Hukum Islam Dan Hukum Positif", Jurnal Penelitian Islam, STAIN Kudus Program Dorktor Pascasarjana IAIN Walisongo Semarang, Vol. III, No.2 Januari-Februari 2019.
}

yang telah lebih dulu mengenal Pegadaian konvensional bukan hal yang mudah. Memerlukan usaha yang sangat giat untuk memperkenalkan dan merebut hati masyarakat. Sehingga pimpinan dan staf melakukan berbagai langka pemasaran dalam memperkenalkan, merebut hati melalui pemasaran produk dan meningkatkan kualitas pelayanannya. UPS Palu Plaza dituntut untuk mempunyai strategi pertahanan untuk merebut dan mempertahankan nasabah melalui kualitas produk dan jasa, yaitu waktu penyerahan lebih cepat, pelayanan lebih baik dibandingkan pesaingnya, dan empati yang tinggi kepada nasabah agar ikut dalam persaingan.

Tabungan emas adalah produk baru di Pegadaian yang melayani pembelian dan penjualan emas dengan fasilitas titipan dengan harga terjangkau. Produk tabungan emas ini diluncurkan dengan tujuan untuk memfasilitasi masyarakat yang ingin membeli emas dengan modal yang seminimal mugkin.Berbeda dengan kredit emas di perbankan, tabungan emas bisa didapat dengan modal yang sangat kecil, tidak ada jangka waktu untuk angsuran, dan tidak menggunakan jaminan apapun. Apalagi bukan hanya orang tua saja yang bisa membuka tabungan emas di Pegadaian, anak sekolah pun juga bisa mulai menabung emas. 
Seiring berjalannya waktu, pegadaian syariah berhasil menduduki peringkat terbaik dan omset tertinggi dimata Kanwil Manado dan berhasil menundukan para pesaing pegadaian yang ada di Kota Palu khususnya Pegadaian yang pertama kali berdiri yaitu Cabang Palu Barat, Cabang Talise, Cabang Palu Timur dan Palu Selatan. ${ }^{7}$

Dari awal peluncurannya tabungan emas mulai menarik minat masyarakat untuk membuka rekening tabungan emas. Dalam teori Black Box yang dipaparkan Kotler, promosi merupakan salah satu faktor dalam proses keputusan pembelian. Promosi merupakan paduan spesifik iklan, promosi penjualan, hubungan masyarakat, penjualan personal, dan sarana pemasaran langsung yang digunakan perusahaan untuk mengomunikasikan nilai pelanggan seacara persuasif dan membangun hubungan pelanggan $^{8}$ Tujuan dengan diadakannya kegiatan promosi yaitu menciptakan atau meningkatkan awareness produk atau brand, meningkatkan preferensi brand pada target pasar, meningkatkan penjualan atau market share, mendorong pembelian ulang merek

\footnotetext{
${ }^{7}$ Anwar Hidayat,Kepala Unit Pengadaian Syariah Cabang Palu Plaza "wawancara" di Ups Cabang Palu Plaza 24 Desember 2018

${ }^{8}$ Philip Kotler dan Gery Amstrong. PrinsipPrinsip Pemasaran, (Jakarta : Penerbit Erlangga 2008), h. 116
}

yang sama, memperkenalkan produk baru, dan menarik pelanggan baru. ${ }^{9}$

Promosi memainkan peranan yang sangat penting dalam menempatkan posisi di mata dan benak pembeli, karena promosi pada hakekatnya untuk memberitahukan, mengingatkan, membujuk pembeli serta pihak lain yang berpengaruh dalam proses pembelian. ${ }^{10}$ Promosi merupakan cara untuk memberitahukan tabungan emas kepada masyarakat sehingga masyarakat mengetahui apa itu tabungan emas dan fungsi dari tabungan emas tersebut. Bauran promosi atau promotional mix dibagi menjadi lima sarana promosi, yaitu periklanan, promosi penjualan, hubungan masyarakat, penjualan personal, dan pemasaran langsung. ${ }^{11}$

Selain itu, pertumbuhan perusahaan jasa harus diikuti dengan kualitas pelayanannya.Pada prinsipnya definisi kualitas jasa berfokus pada upaya pemenuhan kebutuhan dan keinginan pelanggan serta ketepatan penyampaiannya untuk mengimbangi harapan pelanggan. ${ }^{12}$ Pelayanan jasa dari tahun ke tahun harus mengalami peningkatan karena kepuasan

\footnotetext{
${ }^{9}$ Ali Hasan. Marketing, (Yogyakarta : Medpress 2009), h.367

${ }^{10}$ Herry Widagdo. Analisis Pengaruh Kualitas Layanan dan Promosi Terhadap Keputusan Konsumen Membeli Komputer Pada PT. XYZ Palembang. Jurnal Ilmiah STIE MDP Vo1. 1 No. 1 September 2011, h.3

$$
{ }^{11} \text { lbid., h. } 117 .
$$$$
{ }^{12} \text { Fandi Tjiptono. Pemasaran Jasa, }
$$
(Yogyakarta : Bau Media 2011), h.331
} 
pelanggan pada perusahaan jasa menjadi salahsatu aspek dalam memilih suatu produk pada suatu perusahaan.

Bila harapan pelanggan tidak realistis, maka persepsi kualitas total (total perceived quality) akan rendah, walaupun kualitas yang dialami baik. ${ }^{13}$ Kualitas pelayanan yang stagnan dan tidak ada perubahan dalam melayani pelanggan dapat mengakibatkan konsumen akan pindah dari satu perusahaan ke perusahaan lain.

Dalam usaha memasarkan tabungan emas, pihak pegadaian juga harus menumbuhkan motivasimenabung pada diri masyarakat. Masyarakat harus terdorong untuk menabung sehingga masyarakat mau memilih tabungan emas di Pegadaian tersebut.Motivasi merupakan hasrat di dalam seseorang menyebabkan orang tersebut melakukan suatu tindakan. ${ }^{14}$ Sebuah motif atau dorongan adalah kebutuhan yang secara cukup dirangsang untuk mengarahkan seseorang untuk mencari kepuasan. ${ }^{15}$

\section{TINJAUAN PUSTAKA}

\subsection{Konsep Promosi}

\footnotetext{
${ }^{13}$ Ibid.,h. 333.

${ }^{14}$ Wilson Bangun. Manajemen Sumber Daya Manusia. (Jakarta : Penerbit Erlangga 2012), h.312

${ }^{15}$ Philip Kotler dan Gery Amstrong. PrinsipPrinsip Pemasaran, (Jakarta : Penerbit Erlangga 2001), h.212
}

Bagi banyak orang, peluang untuk menghadapi pekerjaan lebih memberikan tantangan, atau untuk lebih mengambil putusan sendiri daripada melaksanakan putusan orang lain, sangatlah menarik. Sesungguhnya keinginan untuk mendiri paling tidak dalam skala minimum atas kemampuan perusahaan, merupakan relisasi kematangan emosional. Jadi, kesempatan untuk promosi sering berperan sebagai faktor pendorong yang sangat penting. Kesempatan tersebut dapat menjawab mengapa para tenaga kerja dengan ijazah-ijazah yang memadai bersedia magang pada pekerjaan yang sebenarnya tidak begitu mereka senangi tetapi memenuhi syarat untuk dipromosikan. Peluang untuk promosi juga menjadi alasan mengapa tenaga kerja muda tidak menerima tawaran pekerjaan sematamata dengan alasan gaji pemulaan yang tinggi. Mereka lebih tertarik kepada jenis pekerjaan yang dapat mempromosikan mereka dengan tingkat gaji yang paling tinggi. ${ }^{16}$

Dalam dunia bisnis, promosi, terutama ditingkat pertama penyeliaan dianggap sebagai imbalan. Karena imbalan tersebut tentu tidak dapat diberikan kepada setiap individu tenaga kerja maka harus dibagikan sedemikian rupa sehingga tidak

\footnotetext{
${ }^{16}$ B.Siswanto Sastrohadiwiryo, Manajemen Tenaga Kerja Indonesia, (Jakarta: Sinar Grafika Offset, 2002), h.257
} 
menyebabkan peda pendapat. Sebagian besar perusahaan yang bersifat konservatif, promosi biasanya hanya didasarkan pada senioritas. ${ }^{17}$ Promosi memiliki makna yang penting bagi perusahaan, sebab dengan kegiatan promosi berarti kelangsungan perusahaan terjaga. ${ }^{18}$

Promosi dapat diartikan sebagai proses berubahan dari satu pekerjaan kepekerjaan lain dalam hierarki wewenang dan tanggung jawab yang lebih tinggi daripada dengan wewenang dan tanggung jawab yang telah diberikan kepada tenaga kerja pada waktu sebelumnya. Promosi adalah proses menaikkan tenaga kerja kepada kedudukan yang lebih bertanggung jawab. Kenaikan tersebut tidak kepada pekerjaan yang lebih berat atau kebebasan beroperasi tetapi kurang penyeliaan. Promosi biasanya diimbangi dengan kenaikan konpensasi bagi tenaga kerja yang bersangkutan. ${ }^{19}$

a. Prinsip Promosi sebagai Langkah Pembinaan Tenaga kerja

Manajemen pada pooknya adalah sekumpulan keterampilan yang melibatkan penerapan prinsip-prinsip tertentu sebagai pedoman untuk melakukan tindakan. Prinsip tersebut dapat diajarkan kepada tenaga kerja atau dapat ia konklusikan, tetapi aplikasinya

\footnotetext{
${ }^{17}$ Ibid.

${ }^{18}$ Ibid., h. 258

${ }^{19}$ Ibid.,
}

hanya dapat dipelajari. Saya dapat mengajarkan prinsip-prinsip pengabdian pada masyarakat kepada anda, tetapi anda tidak akan belajar mengabdi sebelum Anda terjun kemasyarakat luas dan mendapat cara anda sendiri untuk menggunakan prinsipprinsip tersebut. Demikian pula prinsip promosi dapat diajarkan, tetapi satu-satu caranya untuk belajar menggunakannya ialah mencoba mengelolanya. ${ }^{20}$

Promosi sebagai langka pembinaan tenaga kerja mutlak dilakukan manajemen pada setiap hierarki perusahaan. Dengan demikian, promosi dianggap sebagai kegiatan yang telah mendapatkan prioritas perencanaan sebelumnya, bukan hanya merupakan kegiatan yang spontanitas karena merupakan ganjaran atas prestasi sementara tenaga kerja yang bersangkutan.

b. Strategi Promosi

Promosi merupakan kegiatan marketing mix yang terakhir. Dalam kegiatan ini setiap perusahaan berusaha mempromosikan seluruh produk jasa yang dimilikinya, baik langsung maupun tidak langsung.

Tanpa promosi pelanggan tidak dapat mengenal produk atau jasa yang ditawarkan. Oleh karena itu, promosi merupakan sarana yang paling ampuh untuk menarik dan mempertahankan konsumennya. Salah satu

${ }^{20} I$ bid.,h. 259 
tujuan promosi perusahaan adalah menginformasikan segala jenis produk yang ditawarkan dan berusaha menarik calon konsumen yang baru. Paling tidak ada empat macam sarana promosi yang dapat digunakan oleh setiap perusahan dalam mempromosikan produknya, baik barang maupun jasa.

Keempat macam sarana promosi yang dapat digunakan adalah:

1. Periklanan (advertising)

Iklan merupakan saranan promosi yang sering digunakan oleh perusahaaan untuk menginformasikan, menarik, dan memengarui calon konsumennya.

2. Promosi penjualan (sales promotion)

Penggunaan dan pemilihan media iklan tergantung dari tujuan perusahaaan. Masing-masing media memiliki tujuan dan segmentasi sendiri.

3. Publisitas (publicity)

Publisitas merupakan kegiatan promosi untuk memancing pelanggan melalui kegiatan, seperti pameran, bakti social, serta kegiatan lainnya.

4. Penjualan pribadi (personal selling)

Dalam dunia bisnis penjualan pribadi secara umum dilakukan oleh salesman dan salesgirl dengan cara door to door. ${ }^{21}$

c. Tujuan Promosi

${ }^{21}$ Kasmir, Kewirausahaan, (Jakarta: PT. RajaGrafindo Persada, 2006), h. 183.
Hampir setiap kegiatan promosi diharapkan berdampak positif pada perusahaan. Tidak ada perusahaan yang mengharapkan perusahaannya mengalami kemunduran dan kebangrutan. Alternatif jatuh pada pilihan bagaimana melaksanakan program promosi bagi tenaga kerjanya sehingga berdampak positif pada perusahaan. Tujuan yang ingin dicapai melalui kegiatan promosi, antara lain meningkatnya moral kerja, meningkatnya disiplin kerja, terwujudnya iklim oerganisasi yang menggairahkan dan meningkatnya produktivitas kerja.

\subsection{Konsep Kualitas Pelayanan}

a. Pengertian Kualitas Pelayanan

Pada praktiknya terdapat dua sifat jenis pelanggan yaitu pelanggan yang cerewet dan pelanggan atau konsumen yang menerima apa adanya. Karyawan atau instansi yang melakukan kegiatan harus memahami kedua jenis pelanggan tersebut agar pelayanan yang diberikan menjadi maksimal $^{22}$. Tiap jenis pelanggan harus ditangani dan harus diselesaikan dengan cara-cara tersendiri. mengingat karakter kedua jenis pelanggan ini sangat berberbeda.

\footnotetext{
${ }^{22}$ Nurdin, N., \& Yusuf, K. (2020).

Knowledge management lifecycle in Islamic bank: the case of syariah banks in Indonesia. International Journal of Knowledge Management Studies, 11(1), 59-80. doi: 10.1504/ijkms.2020.105073
} 
Pengertian kualitas pelayanan adalah kemampuan sebuah perusahaan memberikan layanan yang dapat membuat pelanggan merasa puas sesuai dengan kebutuhan dan keinginannya. Artinya pelanggan akan terus merasa dan akan terus menambah transaksi atau konsumsinya dari waktu kewaktu. Lebih dari itu, pelanggan akan menceritakan kepuasannya kepada pihak lain, sehingga menjadi ajang promosi gratis bagi perusahaan. Kemampuan memberikan kepuasaan ini juga tidak lepas dari kemampuan sumber daya manusia dalam melayani serta ketersediaan sarana dan prasarana yang dimiliki guna menunjang pelayanan tersebut. $^{23}$

Pekerjaan menjual belum selesai ketika terjadi penjualan. Penjual harus memperbanyak jasa dan bantuan bagi konsumen untuk menjamin kepuasaan mereka dan mengulangi hubungan bisnis. Sayangnya, ini merupakan bagian lain yang sering tidak dikerjakan penjual dengan baik. Wiraniaga seharusnya menindaklanjuti setiap penjualan untuk memastikan bahwa tidak terdapat masalah dengan jadwal pengiriman, mutu barang atau tagihan pelanggan. $^{24}$

${ }^{23}$ Kasmir, Costumer Service Excellent: Teori dan Praktik. (Cet I. Jakarta: PT. RajaGrafindo, 2017), h. 64

${ }^{24}$ Harper W. Boyd, at.all, Marketing Management: A Strategic Approach With Global Orientation. terj Imam Nurmawan. Manajemen Pemasaran: Suatu Pendekatan Strategi dengan
Seperti ditunjukan dalam model dibawah ini, dapat dilihat sesuai dengan arah jarum jam, aspek kualitas juga memiliki implikasi bagi pelayanan pelanggan dan pemasaran produk atau jasa organisasi yang berkualitas seperti yang dilihat oleh pelanggan. ${ }^{25}$

Gambar 1. Unsur Kunci dalam kualitas layanan

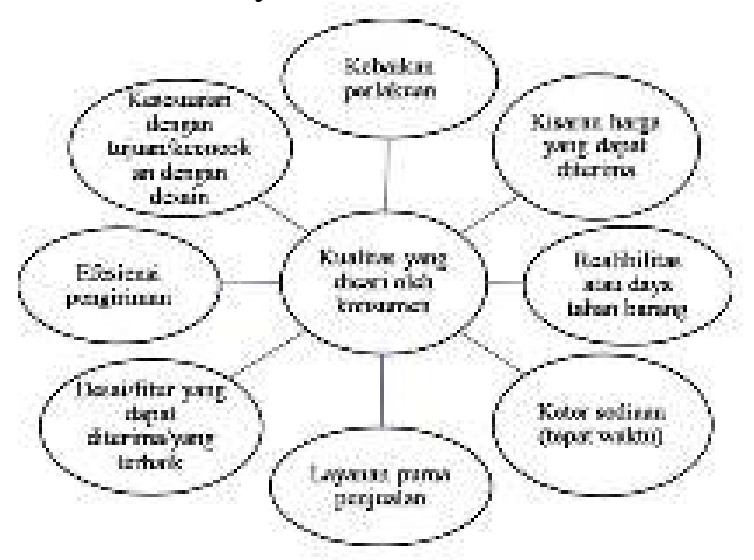

Sumber: Simon A. Burtonshaw-Gun (2011)

\subsection{Konsep Motivasi}

Motivasi merupakan istilah yang lazim digunakan untuk mengetahui maksud seseorang atas suatu hal untuk mencapai tujuan tertentu, misalnya uang, keselamatan, prestise, dan sebagainya. Namun demikian, tujuan khusus yang tampaknya diperjuangkan banyak orang dalam analisis kerapkali berubah menjadi alat untuk mencapai tujuan lain, yang dipandang lebih fundamental. Dengan demikian, kekayaan,

Orientasi Global, (Edisi II Jilid ii. Jakarta: Erlangga, 2000), h. 110

${ }^{25}$ Farida Jasfar, Manajemen Jasa: Pendekatan terpadu. Bogor: Ghalia Indonesia, 2005, h. 51 
rasa aman (keselamatan), atatus, dan segala macam tujuan lain yang dipandang sebagai "kausalitas" perilaku hanya merupakan hiasan semata-mata untuk mencapai tujuan akhir setiap orang, yakni menjadi diri sendiri.

Motivasi terakhir setiap individu adalah merealisasikan konsep dirinya: hidup dalam suatu cara yang sesuai dengan peran yang lebih disukai, diperlukan sesuai dengan tingkatan yang lebih disukai, dan dihargai sesuai dengan cara yang mencerminkan penghargaan seseorang atas kemampuannya. Oleh karena itu, individu snantiasa mencari apa yang mereka pandang sebagai peran yang cocok bagi dirinya, sambil berusaha merealisasikan gagasan subjektif mengenai dirinya sebagai kebenaran objektif. Pengalaman individu hamper senantiasa membenarkan kenyakinannya bahwa sikap dasar individu harus benar, karna sikap tersebut sesuai dengan realitas lingkungan hidup yang khas karena individu menghargai pengalaman dan pengelolanya sesuai dengan lingkungan tersebut kedalam system kenyakinan individu.

Barelson dan Steiner mendefinisikan motivasi sebagai "all those inner striving conditions variously described as wishes, desire, needs, drives, and the like" (Machrany,1985). Dengan demikian, motivasi dapat diartikan sebagai keadaan kejiwaan dan sikap mental manusia yang menberikan energi, mendorang kegiatan atau menggerakkan dan mengarah atau menyalurkan prilaku kearah mencapai kebutuhan yang memberi kepuasan atau mengurangi ketidakseimbangan.

Bentuk motivasi dalam praktek, hampr dalam setiap perusahaan menganut versinya sendiri yang lebih kurang tradisional dalam mengancang motivasi. Perbedaan yang terdapat antara satu perusahaan dengan perusahaan lain dalam pemberian motivasi hampir selalu terletak pada gaya, selera, atau tekanan, dan bukandalam jenisnya. ${ }^{26}$

\subsection{Konsep Keputusan Memilih}

Suatu keputusan dapat dibuat hanya jika ada beberapa alternatif yang dipilih. Apabila alternatif pilihan tidak ada maka tindakan yang dilakukan tanpa adanya pilihan tersebut tidak dapat dikatakan membuat keputusan. ${ }^{27}$

Secara umum manusia bertindak rasional dan mempertimbangkan segala jenis informasi yang tersedia dan mempertimbangkan segala sesuatu yang mungkin bisa muncul dari tindakannya sebelum melakukan sebuah perilaku tertentu Konsumen yang terangsang kebutuhannya akan mulai terdorong untuk mencari informasi yang lebih banyak. Konsumen

\footnotetext{
${ }^{26}$ Ibid., h. 270

${ }^{27}$ Philip Kotler and Kellerd, Kevin Lane. Marketing managemen. $14^{\text {th }}$ edition. New Jersey:Prentice 2012, h. 166
} 
dalam tahap ini dapat dibagi menjadi dua level. Pertama: penguatan perhatian. Level ini menunjukan situasi pencarian bersifat lebih ringan, hanya sekedar lebih peka pada informasi produk. Kedua: aktif mencar informasi. Konsumen akan lebih aktif untuk mencariinformasi melalui bahan bacaan, menelpon teman maupun mengunjungi toko untuk mempelajari suatu produk.

Perilaku konsumen merupakan unsur penting dalam kegiatan pemasaran suatu produk yang perlu diketahui oleh perusahaan, karena perusahaan pada dasarnya tidak mengetahui mengenai apa yang ada dalam pikiran seorang konsumen pada waktu sebelum, sedang, dan setelah melakukan pembelian produk tersebut ${ }^{28}$.

Konsumen berasal dari bahasa asing (belanda inggris), consumen dan consumer yang arti harfiahynya adalah pembeli. Pengertian lain dari konsumen sangat luas, beragam dan sangat terkait erat dengan tujuan seseorang membeli suatu produk misalnya sebagai pengguna yang diterjemahan dari kata user dari kata bahasa inggris. Pengertian lain dari konsumen adalah pemakai, pemirsa, dan masih banyak lagi. $^{29}$

${ }^{28}$ Nurdin, N., Novia, N., Rahman, A., \& Suhada, R. (2019). Potensi Industri Produk Makanan Halal Di Kota Palu. Jurnal Ilmu Ekonomi dan Bisnis Islam, 1(1), 1-12.

${ }^{29} \mathrm{H}$. Mulyadi Nasusastro, Perilaku Konsumen dalam Perspektif Kewirausahaan (Bandung: Alfabeta, 2012) h. 24.

\subsection{Kerangka Pikir}

Pengaruh Promosi, kualiatas pelayanan dan motivasi erat kaitannya denngan keputusan memilih produk. Pengaruh promosi, kualitas pelayan dan motivasi merupakan penilaian menyeluruh atas suatu tingkat pelayanan yang baik, sedangkan keputusan memilih adalah tingkat perasaan seseorang setelah membandingkan hasil kinerja yang dirasakan dibanding dengan harapannya.

Keputusan memilih dapat tercipta dengan adanya pengaruh promosi diimbangi dengan kualitas pelayanan yang diberikan perusahaan dan motivasi yang timbul dalam diri. Dengan kata lain semakin besar pengarus promosi, baiknya kualitas pelayanan serta timbulnya motivasi pada diri maka akan semakin besar keputusan nasabah untuk memilih produk tabungan emas di Pengadain Syariah Cabang Palu Plaza.

Berdasarkan penjelasan diatas maka kerangka pemikiran dalam penelitian ini adalah sebagai berikut :

Gambar 2. Model Penelitian

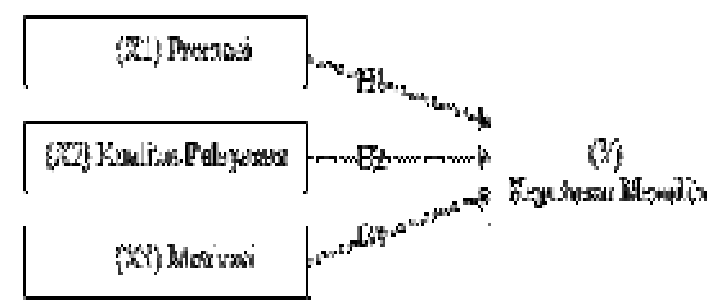

3. METODE PENELITIAN 
Penelitian ini menggunakan pendekatan kualitatif ${ }^{30}$ dengan pendekatan survey $^{31}$. Kegiatan penelitian meliputi data, analisis, dan interpretasi tetang arti dari data yang diperoleh, instrument penelitian ini menggunakan kuesioner. penelitian ini juga dimaksud untuk mengetahui pengaruh promosi, kualitas pelayanan, dan motivasi terhadap keputusan memilih produk tabungan emas.Lokasi penelitian yang dilakukan bertempat di Pegadaian Syariah Palu Plaza.

Sampel dalam penelitian ini adalah semua nasabah yang menggunakan tabungan emas Pegadaian Syariah Cabang Palu Plaza dari tahun 2018. Untuk menemukan jumlah sampel yang diperlukan, maka peneliti menggunakan rumus slovin dalam Siregar yaitu: ${ }^{32}$. Berdasarkan pendekatan Slovin, maka sampel penelitian ini sebanyak 92 dari jumlah populasi 1147 orang.

Alat ukur dalam penelitian biasanya dinamakan instrument penelitian. Jadi instrumen penelitian ini adalah suatu alat

\footnotetext{
${ }^{30}$ Miller, K. (2001). Quantitative Research Method in The New Hanbook of Organziational Communication: Advances in Theory, Research and Methods by frederick M. Jablin and Linda L. Putnam (Editors), London : Sage Publications.

${ }^{31}$ Boose, J. H. (1989). A survey of knowledge acquisition techniques and tools. Knowledge Acquisition, 1(1), 3-37. doi: https://doi.org/10.1016/S1042-8143(89)80003-2

${ }^{32}$ Sofyan Siregar, Metode Penelitian Kuantitatif (dilengkapi dengan perbandingan perhitungan manual dan SPSS) (Jakarta: Kencana, 2013),34.
}

yang digunakan mengukur fenomena alam maupun sosial yang diamati. $^{33}$ Karena instrumen penelitinan akan digunakan untuk melakukan pengukuran dengan tujuan menghasilkan data kuantitatif yang akurat, maka setiap instrumen harus mempunyai skala. Penelitian ini menggunakan skala likert. Data diolah dengan menggunakan aplikasi statistic SPSS.

\section{HASIL DAN PEMBAHASAN}

\subsection{Uji Validitas dan Realibilitas}

Menggunakan instrument yang valid dan realibel dalam pengumpulan data, maka diharapkan hasil penelitian akan menjadi valid dan realibel.

Instrument yang dinyatankan valid dan realibel adalah: instrument yang valid, berarti alat ukur yang digunakan untuk mendapatkan data (mengukur) itu valid. Sedangkan instrument yang realibel berarti bila digunakan untuk mengukur berkali-kali akan menghasilkan data yang sama.

Menurut sugioyono dalam sakinah, apabila validitas setiap jawaban yang diperoleh ketika memberikan daftar peryataan lebih besar dari 0,3 maka pernyataan dianggap sudah valid. ${ }^{34}$

\footnotetext{
${ }^{33}$ Sugiyono, Metode Penelitian Kombinasi,
} (Bandung: CV Alfabeta, 2015), h.136.

${ }^{34}$ Sakinah, Pengaruh Bauran Pemasaran Keputusan Membeli Kartu Prabayar Produk 
Melihat Butir pertanyaan atau pernyataan yang valid adalah dengan melihat tabel Item Total Statistion.

Tabel 1. Hasil Uji Validitas Instrumen

\begin{tabular}{|c|c|c|c|c|}
\hline Yuind & $\begin{array}{c}\text { Ters } \\
\text { Axacuava }\end{array}$ & 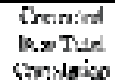 & فئis & ber. \\
\hline & 1 & 6.472 & $\dot{r}_{10} 0$ & Pials \\
\hline \multirow{4}{*}{ 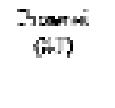 } & $t$ & 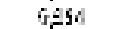 & 0.10 & $y / d x$ \\
\hline & 9 & $0: 1 \%$ & $R, 70$ & $v=1,4$ \\
\hline & $d$ & 6,585 & $\sec 0$ & Wald \\
\hline & 1 & tified & 8,150 & $v_{\mathrm{a}}$ \\
\hline Sinsion & 9 & עak & 6,50 & $\psi 4 \mathrm{~d} h \mathrm{~h}$ \\
\hline \multirow{3}{*}{ Doluen } & $\underline{x}$ & 9.रण & 8.50 & vitu \\
\hline & 4 & श,4 & 8,50 & Wallo \\
\hline & $i$ & $B, 40$ & 430 & Faj \\
\hline \multirow{5}{*}{$\begin{array}{c}\text { Qu vituss } \\
\text { (x.7. }\end{array}$} & 1 & D,jill & 5,32 & Vilid \\
\hline & 2 & 0.16 & Q⿻日木 & val \\
\hline & 4 & 6791 & $2 \%$ & Filji \\
\hline & 8 & Disly & $8=$ & Valid \\
\hline & $=$ & $0.12 x$ & 204 & VIH \\
\hline \multirow{4}{*}{ 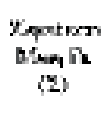 } & 1 & 0419 & $\Leftrightarrow ; 0$ & Shlid. \\
\hline & $?$ & 0.472 & $\mathrm{~A} H$ & Fis \\
\hline & 5 & $60 \mathrm{HO}$ & 250 & v.lu \\
\hline & 1 & $0, \pi$ & $\Leftrightarrow$ & 5 stix \\
\hline
\end{tabular}

Tabel diatas, terlihat bahwa nilai rhitungpada kolom Corrected Item TotalCorrelation untuk masing-masing dari ke 4 variabel diatas dinyatakan semua

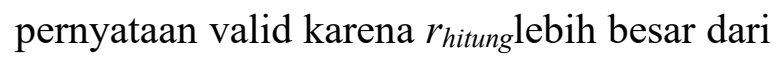
positif dari 0,30 .

\section{Uji Reliabilitas}

Melakukan pengujian reliabilitas dalam penelitian ini digunakan program SPSS (Statistical Packaged For Sosial Siences) versi 16 dimana dalam mengukur reliabilitas disini menggunakan uji statistic Cronbach'sAlpha (a). Suatu instrument dinyatakan reliable jika memiliki Cronbach's Alpha(a) lebih dari 0,60.

Tabel 2. Hasil Uji Reliabilitas

Telkomsel Pada Mahasiswa IAIN Palu, Skripsi (Palu: IAIN 2014), 5.

\begin{tabular}{|c|c|c|c|}
\hline $\begin{array}{c}\text { Vinsul::1 } \\
\text { Powasi (XI) }\end{array}$ & $\begin{array}{c}\text { Reliabilin: } \\
\text { Cos:Axsun } \\
\text { 1 Jtem }\end{array}$ & $\begin{array}{c}\text { Cronts:h } \\
\text { Alyilue } \\
0,5 \pm S\end{array}$ & 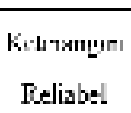 \\
\hline KLalikex l':lkymuen (XZ) & Y|เบแ" & 0.69 & Karlmis: \\
\hline Kaxver $\left(x^{2}\right)$ & 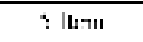 & 0,611 & Kn:lumis: \\
\hline 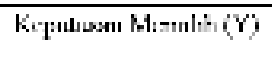 & 4 | I I & $0 \sin 0$ & k:luth: \\
\hline
\end{tabular}

Tabel diatas dapat diketahui bahwa masing-masing variabel memiliki Cronbach's Alpha (a) lebih dari 0,60 (a > $0,60)$, yang artinya bahwa semua variabel yaitu X1, X2, X3 dan Y adalah realibel. Dengan demikian pengolahan data dapat dilanjutkan ke jenjang selanjutnya.

\subsection{Uji Asumsi Klasik}

Sebelum metode regresi digunakan dalam pengujian hipotesis, terlebih dahulu model tersebut akan diuji apakah memenuhu asumsi klasik adalah persyaratan statistik yang harus dipenuhi pada analisis regresi linear berganda. Asumsi klasik dimaksudkan untuk mengetahui apakah koefisien regresi yang didapatkan telah benar dan dapat diterima serta menghindari kemungkinan adanya pelanggaran asumsi klasik yang merupakan asumsi dasar dalam metode analisis regresi. Hasil uji asumsi klasik disajikan sebagai berikut:

\subsection{Uji Asumsi Normalitas}

Uji normalitas digunakan untuk mengetahui apakah data yang disajikan untuk dianalisis lebih lanjut berdistribusi normal atau tidak. Model regresi yang baik adalah distribusi distribusi data normal atau 
mendekiti normal. Adapun cara untuk mendeteksinya, yaitu dengan analisis analisis grafik.

Analisis grafik merupakam cara untuk melihat normalitas residual yaitu dengan melihat grafik histogram yang membandingkan data observasi dengan distribusi yang mendekati distribusi normal. Model lain yang digunakan dalam analisis grafik adalah dengan melihat normal Probability Plot yang membandingkan kumulatif dari distribusi normal. Jika distribusi data residual normal, maka garis yang akan menggambarkan data yang sesungguhnya akan mengikuti garis diagonalnya. Dengan menggunakan SPSS for Windows versi 16baru terlihat grafik distribusi normal sebagai berikut:

Gambar 3. Histogram

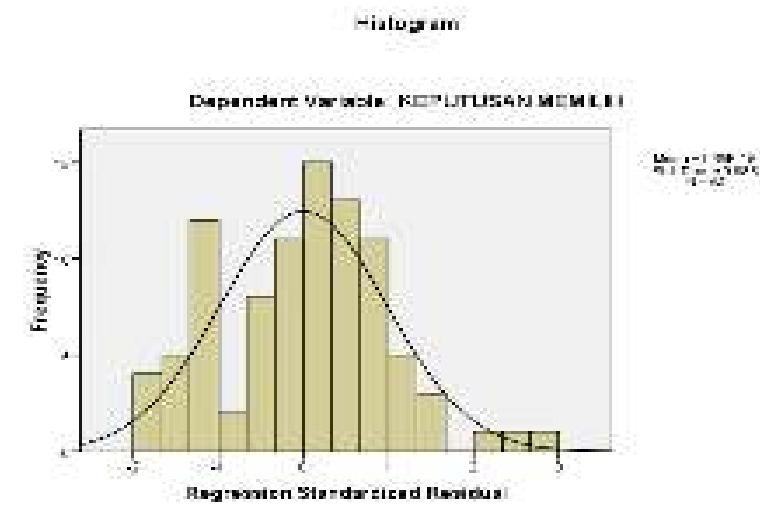

Grafik histogram diatas menunjukkan bahwa data penelitian menunjukkan bentuk normal karena mengikuti bentuk distribusi normal dimana pola distribusi yang normal tidak terjadi kemiringan, sehingga dapat disimpulkan bahwa distribusi data penelitian ini telah memenuhi asumsi normalitas data.

Sedangkan hasil dari grafik Probability Plot (P-Plot) dari program SPSS for Windows Release 16adalah sebagai berikut:

\section{Gambar 4. Hasil Uji Asumsi Klasik Normalitas}

Narmal P.P Plot of Regression Standardized Residual

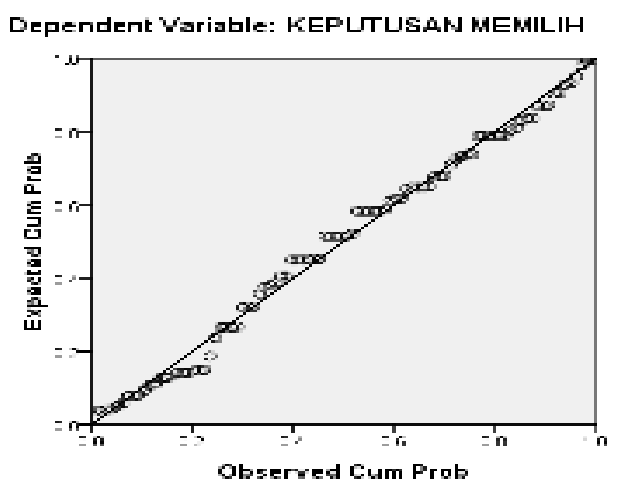

Jika data menyebar disekitar garis diagonal, maka model regresi memenuhi asumsi normalitas.

\subsection{Uji Heteroskedastisitas}

Uji Heteroskedastisitas dilakukan untuk mengetahui apakah dalam model regresi terjadi kesalahan varians dari residual suatu pengamatan ke pengamatan lain, jika varians dari residual dari suatu pengamatan ke pengamatan lain berbeda maka disebut heteroskedasitas. Model regresi terbaik adalah yang tidak terjadi heteroskedasitas. Untuk menguji asumsi ini dilakukan dengan melalui grafik scatterplot antara variabel terikat (ZPRED) dan variabel bebas (ARESID). 
Gambar 5. Hasil Uji Asumsi Klasik Heteroskedastisitas

5xidte juet

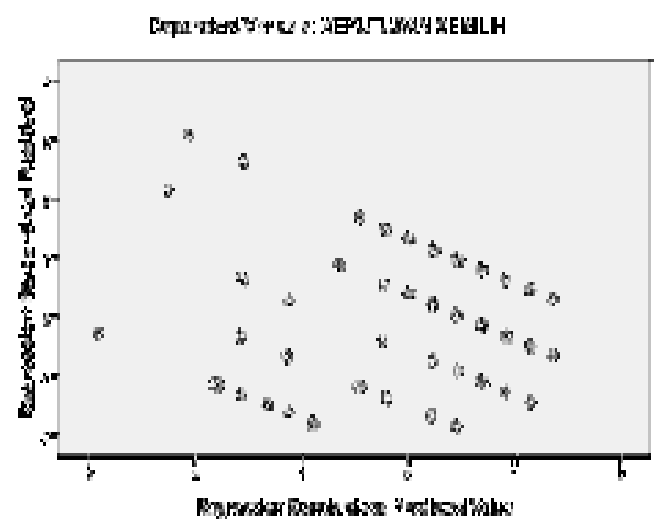

Berdasarkan gambar grafik di atas terlihat bahwa titik-titik atau poin-poin menyebar di atas dan di bawa angka 0 dan sumbu Y. Maka dapat disimpulkan bahwa tidak terjadi heteroskedastisitas pada model regresi.

\subsection{Uji Multikolinearitas}

Multikolinearitas bertujuan untuk menguji apakah pada model regresi berganda ditemukan adanya kolerasi antara independen. Jika terjadi kolerasi, maka dinamakan terdapat problem multikolinearitas (multiko).

Membuktikan ada tidaknya Multikolinearitas dengan melihat nilai Tolerance dan Variance Inflation Factor (VIF). Koefisien kolerasi antara variabel haruslah lemah (dibawah 0,10). Jika kolerasi kuat maka terjadi problem multiko.
Pada tabel berikut ini dapat dilihat hasil uji multikolinearitas yang menunjukkan nilai VIF dan tolerance untuk masingmasing variabel independen.

Tabel 3. Hasil Uji Multikolinearitas

\begin{tabular}{|c|c|c|}
\hline \multirow{2}{*}{ Modal } & \multicolumn{2}{|c|}{ Collinearity Statistics } \\
\cline { 2 - 3 } & Tolerance & VIF \\
\hline 1 (constant) & & \\
Promosi & 0,754 & 1,326 \\
Kualitas Pelayanan & 0,897 & 1,115 \\
Motivasi & 0,752 & 1,379 \\
\hline
\end{tabular}

Sumber: Data Ouput SPSS 16

Berdasarkan tabel tersebut, menunjukkan bahwa dalam model regresi bebas dari adanya multikolinear. Hal ini dapat dilihat dari perhitungan nilai Tolerancemenunjukkan tidak ada variabel independen yang memiliki nilai Toleranceyang kurang dari 0,10. Selain itu, hasil perhitungan nilai Variance Inflation Factor (VIF) juga menunjukkan hal yang sama yaitu tidak ada satupun variabel independen yang menunjukkan nilai VIF lebih dari 10. Jadi dapat disimpulkan bahwa tidak ada Multikolinearitas antara variabel independen dalam model regresi.

\subsection{Analisis Regresi Linear Berganda}

Analisis regresi linear berganda adalah salah satu alat statistik nonparametrik yang berfungsi menganalisis keterkaitan dan keterhubungan diantara dua atau lebih variabel penelitian yang berbeda, yaitu variabel dependen dan independen dengan membutuhkan data terdiri dari beberapa 
kelompok hasil observasi pengukuran. Selanjutnya dari hasil analisis regresi berganda ini akan diketahui ada tidaknya pengaruh secara parsial dan simultan variabel Promosi (X1), Kualitas Pelayanan (X2), dan Motivasi (X3) terhadap Keputusan Memilih Nasabah.

Berdasarkan hasil oleh data penggunakan SPSS 16 for windows diperoleh hasil analisis regresi berganda sebagai berikut.

Tabel 4. Hasil Analisis Regresi Linear Berganda

\begin{tabular}{|c|c|c|c|c|c|c|c|}
\hline \multicolumn{8}{|c|}{ "ivoro: } \\
\hline \multirow[t]{3}{*}{ Vibosd } & \multirow{2}{*}{\multicolumn{2}{|c|}{ 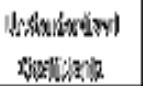 }} & Moluiral & \multirow[t]{3}{*}{1} & \multirow[t]{3}{*}{94.} & \multirow{2}{*}{\multicolumn{2}{|c|}{ 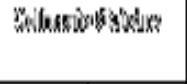 }} \\
\hline & & & 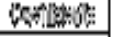 & & & & \\
\hline & $\%$ & 经 & $n x$ & & & Thisisis & 虾" \\
\hline Whutson & sitit & 2kte & & $i, i 18$ & wh & & \\
\hline t & (N) & i is & 到 & $i / \gamma^{2}$ & doth & 禹绐 & "xere \\
\hline$x$ & | & 20: & , 20: & $\alpha$ & sis & 藕 & PAN \\
\hline 5 & 然 & ; & 踏 & $\$ A^{\prime}$ & 3 & Niol & $2 x$ \\
\hline
\end{tabular}

Hasil analisis regresi linear berganda pada table di atas, kemudian dimasukkan ke dalam model persamaan regresi berganda sebagai berikut:

$$
Y=2,568+0,171 X_{1}+0,180 X_{2}+
$$

\section{$\mathbf{0 , 3 6 7 X _ { 3 }}$}

Persamaan regresi linear berganda diatas menunjukkan bahwa ketiga variabel independen (Promosi, Kualitas Pelayanan dan Motivasi). Hasil perhitungan diatas dapat dijelaskan sebagai berikut:Konstanta positif sebesar 2,568 mempunyai arti keputusan memilih nasabah akan meningkat sebesar 2,568 jika variabel promosi, kualitas pelayanan dan motivasi konstan atau bernilai nol (0).

a. Koefisien regresi promosi (X1) sebesar 0,171 bernilai fositif. Nilai fositif $(+)$ pada variabel promosi mempunyai makna searah, artinya bahwa setiap terjadinya peningkatan satu satuan variabel promosi (X1) akan meningkatkan keputusan memilih sebesar 0,171 jika variabel lain dianggap konstan.

b. Koefisien regresi kualitas pelayanan (X2) sebesar 0,180 bernilai fositif. Nilai fositif $(+)$ pada variabel promosi mempunyai makna searah, artinya bahwa setiap terjadinya peningkatan satu satuan variabel kualitas pelayanan (X2) akan meningkatkan keputusan memilih sebesar 0,180 jika variabel lain dianggap konstan.

c. Koefisien regresi motivasi (X3) sebesar 0,367 bernilai fositif. Nilai fositif $(+)$ pada variabel promosi mempunyai makna searah, artinya bahwa setiap terjadinya peningkatan satu satuan variabel motivasi (X3) akan meningkatkan keputusan memilih sebesar 0,367 jika variabel lain dianggap konstan.

4.7 Uji F (Uji Simultan) 
Pengujian ini ingin mengetahui apakah variabel independen $(\mathrm{X})$ berpengaruh secara bersama-sama memberikan kontribusi secara signifikan terhadap variabel dependen.

Tabel 5. Uji Simultan F

\begin{tabular}{|c|c|c|c|c|c|}
\hline \multicolumn{6}{|c|}{ 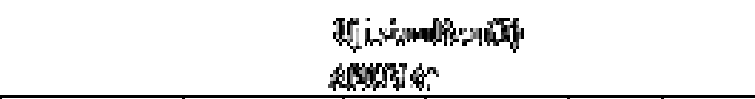 } \\
\hline woskt. & 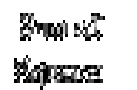 & $\operatorname{Ir} \dot{F}^{\prime \prime}$ & 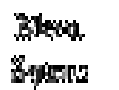 & 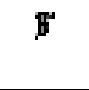 & 酸 \\
\hline 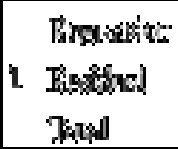 & 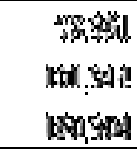 & $\begin{array}{l}5 \\
8 \\
8\end{array}$ & 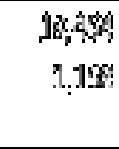 & Wh: & sto \\
\hline
\end{tabular}

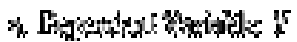

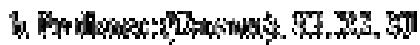

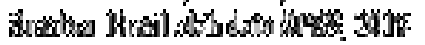

Berdasarkan hasil uji Anova (Analisis Of Varians), atau $\mathrm{F}$ tes diperoleh nilai $F_{\text {hitung }}$ sebasar $16,79>F_{\text {tabel }} 2,70$ dengan nilai Sig sebesar 0,000 kecil dari dibanding alpha 0,05. Dengan demikian hasil ini memberikan makna bahwa variabel Promosi (X1), Kualitas Pelayanan (X2), dan Promosi (X3) secara simultan berpengaruh signifikan terhadap keputusan memilih (Y).

\section{Uji T (Uji Parsial)}

Uji parsial digunakan untuk menguji apakah variabel independen benar-benar memberikan kontribusi terhadap variabel dependen. Berikut dibawah ini tabel hasil uji T pada tabel coeficients.
Tabel 6. Uji Parsial (uji T)

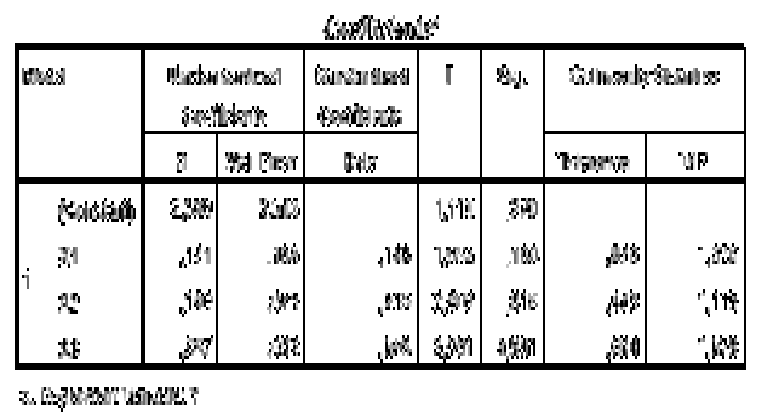

Berdasarkan hasil perhitungan statistik uji $\mathrm{T}$ dari 3 variabel independen yang dimaksud dalam model regresi terlihat bahwa:

a. Promosi (X1) diperoleh nilai thitung $1,662<$ $\mathrm{t}_{\text {tabel }} 1,987$ dan memiliki nilai signifikan (sig) 0,10 pada table coefficients dengan nilai $a$ (tingkat signifikan) 0,05 . Artinya $0,10>0,05$. Dengan nilai ini memberikan makna bahwa secara parsial variabel Promosi (X1) tidak memberikan pengaruh yang signifikan terhadap keputusan memilih (Y). Adapun besaran pengaruhnya dapat dilihat pada kolom beta. Besaran pengaruh variabel X1 terhadap variabel Y yaitu 16,3\%

b. Kualitas Pelayanan (X2) diperoleh nilai $t_{\text {hitung }} 2,408>t_{\text {tabel }} 1,987$ dan memiliki nilai signifikan (sig) 0,18 pada table coefficients dengan nilai $a$ (tingkat signifikan) 0,05. Artinya $0,01<0,05$. Dengan nilai ini memberikan makna bahwa secara parsial variabel Kualitas Pelayanan (X2) memberikan pengaruh secara signifikan terhadap keputusan 
memilih (Y). Adapun besaran pengaruhnya dapat dilihat pada kolom beta. Besaran pengaruh variabel X1 terhadap variabel Y yaitu 21,6\%

c. Motivasi (X3) diperoleh nilai thitung 3,991 $>t_{\text {tabel }} 1,987$ dan memiliki nilai signifikan (sig) 3,99 pada table coefficients dengan nilai $a$ (tingkat signifikan) 0,05 . Artinya 3,99>0,05. Dengan nilai ini memberikan makna bahwa secara parsial variabel Motivasi (X3) tidak memberikan pengaruh signifikan terhadap keputusan memilih (Y). Adapun besaran pengaruhnya dapat dilihat pada kolom beta. Besaran pengaruh variabel X3 terhadap variabel Y yaitu 39,8\%

d. Jadi, dari beberapa variabel pengaruh yang diteliti. Maka, variabel pengaruh yang paling besar pengaruhnya terhadap keputusan memilih Produk Tabungan Emas Di Pegadaian Syariah Cabang Palu Plaza Kota Palu adalah variabel 21,6\%

\subsection{Koefisien Determinasi}

Analisis koefisien determinasi dilakukan untuk mengetahui seberapa besar persentase kontribusi independen (X) terhadap variabel dependen (Y). Dari hasil perhitungan melalui alat ukur statistik SPSS 16 for windows didapatkan nilai koefisien determinasi sebagai berikut.

Gambar 7. Hasil Koefesien Determinasi

\subsection{Pembahasan}

Hasil menguji dengan menggunakan analisis regresi berganda dengan bantuan SPSS 16 for Windows, pengaruh terhadap keputusan memilih produk Tabungan Emas Pegadaian Syariah Cabang Palu Plaza menunjukkan bahwa secara simultsnmemiliki pengaruh positif terhadap keputusan memilih nasabah. Begitu pula dengan pengaruh masing-masing variabel secara varsial masing-masing memiliki pengaruh dengan besaran pengaruh yang berbeda.

Berdasarkan hasil uji Anova analisis data, dengan hasil $F_{\text {hitung }} 16,79>F_{\text {tabel }} 2,70$ dengan nilai Sig sebesar 0,000 kecil dari 
dibanding alpha 0,05. Dengan demikian hasil ini memberikan makna bahwa variabel Promosi (X1), Kualitas Pelayanan (X2), dan Promosi (X3) secara simultan berpengaruh signifikan terhadap keputusan memilih (Y).

1. Pengaruh Promosi Terhadap Keputusan Memilih Produk Tabungan Emas

Berdasarkan hasil uji statistik diperoleh nilai $t_{\text {hitung }} 1,662<\mathrm{t}_{\text {tabel }} 1,987$ dan memiliki nilai signifikan (sig) 0,10 pada table coefficients dengan nilai $a$ (tingkat signifikan) 0,05 . Artinya $0,10>0,05$. Dengan nilai ini memberikan makna bahwa secara parsial variabel Promosi (X1) tidak memberikan pengaruh yang signifikan terhadap keputusan memilih (Y). Adapun besaran pengaruhnya dapat dilihat pada kolom beta. Besaran pengaruh variabel X1 terhadap variabel Y yaitu 16,3\%. Hasil ini dapat memberikan gambaran bahwa responden (nasabah) memandang bahwa Promosi yang dilakukan oleh Pegadaian belum mampu secara signifikan mempengaruhi keputusan nasabah untuk memilih produk Tabungan Emas Di Pegadaian Syariah Cabang Palu Plaza.

Dari hasil pengujian pada hipotesis pertama, menunjukkan bahwa Promosi tidak berpengaruh signifikan terhadap Keputusan Memilih Produk. Hasil ini bertentangan dengan hasil penelitian yang dilakukan oleh Herry Widagdo (2011) dan Rindang Lista Sari (2014) yang menyatakan bahwa
Promosi berpengaruh signifikan terhadap Keputusan Memilih Produk. Akan tetapi hasil ini sejalan dengan penelitian yang dilakukan oleh Asih Purwanto (2008) yang menyatakan bahwa Promosi tidak berpengaruh signifikan terhadap Keputusan Memilih Produk. Hal ini dapat dilihat dari nilai probabilitas sebesar 0,10 . Nilai signifikansi $0,10<0,05$ menunjukkan bahwa variabel Promosi tidak memiliki pengaruh yang signifikan terhadap Keputusan Memilih Produk Tabungan Emas Di Pegadaian Syariah Cabang Palu Plaza Kota Palu.

2. Pengaruh Kualitas Pelayanan Terhadap Keputusan Memilih Produk Tabungan Emas

Berdasarkan hasil uji statistik diperoleh nilai $t_{\text {hitung }} 2,408>\mathrm{t}_{\text {tabel }} \quad 1,987$ dan memiliki nilai signifikan (sig) 0,18 pada table coefficients dengan nilai $a$ (tingkat signifikan) 0,05 . Artinya $0,01<0,05$. Dengan nilai ini memberikan makna bahwa secara parsial variabel Kualitas Pelayanan (X2) memberikan pengaruh secara signifikan terhadap keputusan memilih (Y). Adapun besaran pengaruhnya dapat dilihat pada kolom beta. Besaran pengaruh variabel X1 terhadap variabel $\mathrm{Y}$ yaitu 21,6\%. Hasil ini dapat memberikan gambaran bahwa responden (nasabah) memandang bahwa Kualitas Pelayanan yang dilakukan oleh Pegadaian mampu secara signifikan mempengaruhi keputusan nasabah untuk 
memilih produk Tabungan emas di pegadaian Syariah Cabang Palu Plaza.

Sesuai dengan hasil jawaban responden yang ada bahwa 23 responden atau $25 \%$ yang setuju dengan pernyataan bahwa Pegawai Pegadaian Syariah Berpakai Rapi dan 29 responden atau 31,5\% yang setuju dengan pernyataan Kemampuan Pelayanan Pegadaian Syariah Dalam Melaksanakan Jasa Yang Dijanjikan Tepat Waktu. Sehingga nasabah dapat memilih produk Tabungan Emas Di Pegadaian Syariah Cabang Palu Plaza.

3. Pengaruh Motivasi Terhadap Keputusan Memilih Produk Tabungan Emas

Berdasarkan hasil uji statistik diperoleh nilai thitung 3,991 $>t_{\text {tabel }} 1,987$ dan memiliki nilai signifikan (sig) 3,99 pada table coefficients dengan nilai a (tingkat signifikan) 0,05 . Artinya 3,99>0,05. Dengan nilai ini memberikan makna bahwa secara parsial variabel Motivasi (X3) tidak memberikan pengaruh signifikan terhadap keputusan memilih (Y). Adapun besaran pengaruhnya dapat dilihat pada kolom beta. Besaran pengaruh variabel X3 terhadap variabel Y yaitu 39,8\%. Hasil ini dapat memberikan gambaran bahwa responden (nasabah) memandang bahwa Motivasi yang dilakukan oleh Pegadaian belum mampu secara signifikan mempengaruhi keputusan nasabah untuk memilih produk Tabungan emas di pegadaian Syariah Cabang Palu Plaza.

Dari hasil pengujian pada hipotesis ketiga, menunjukkan bahwa Motivasi tidak berpengaruh signifikan terhadap Keputusan Memilih Produk. Hasil ini bertentangan dengan hasil penelitian yang dilakukan oleh Urip Wahyuni (2008)yang menyatakan bahwa Motivasi berpengaruh signifikan terhadap Keputusan Memilih Produk. Akan tetapi hasil ini sejalan dengan penelitian yang dilakukan oleh Bilondatu (2013) yang menyatakan bahwa Motivasi tidak berpengaruh signifikan terhadap Keputusan Memilih Produk. Hal ini dapat dilihat dari nilai probabilitas sebesar 3,99. Nilai signifikansi 3,99<0,05 menunjukkan bahwa variabel Motivasi tidak memiliki pengaruh yang signifikan terhadap Keputusan Memilih Produk Tabungan Emas Di Pegadaian Syariah Cabang Palu Plaza Kota Palu.

\section{KESIMPULAN}

Berdasarkan rumusan masalah dan hasil penelitian diketahui bahwa hasil pada penelitian ini menjelaskan:

1. bahwa secara simultan promosi, kualias layananan, dan motivasiberpengaruh dan signifikan terhadap keputusan memilih produk tabungan emas.

2. Secara parsial, variabel promosi (X1) tidak berpengaruh terhadap keputusan memilih produk tabungan emas. 
3. Secara parsial, variabel kualitas pelayanan (X2) berpengaruh terhadap keputusan memilih produk tabungan emas.

4. Secara parsial, variabel motivasi (X3) tidak berpengaruh terhadap keputusan memilih produk tangungan emas.

\section{Daftar Pustaka}

Departemen Agama Republik Indonesia, AlQur'an dan Terjemahannya, Surabaya: Mekar Surabaya, 2004.

Alma, Buchari. Manajemen Bisnis Syariah. Cet. 1; Bandung: Alfabet, 2009.

Anshari, Abdul Ghofur.Gadai Syariah di Indonesia. Jakarta: Gajah Mada Univesity Press, 2006.

Al-Mahali, Al-Imam Jalaluddin Muhammad dan Al-Iman Jalaluddin Abdurrahman As-Suyuthi. Tafsir Jalalain. Jilid 1 Surabaya: PT Elba Fitra Mandiri Sejahtera, 2015.

Bangun, Wilson. Manajemen Sumber Daya Manusia. Jakarta : Penerbit Erlangga, 2012.

Baladraf, Nafila. Pengaruh Nilai Taksiran Terhadap Motivasi Nasabah dalam Menggadaikan Emas di Unit Gadai Bank Syariah Mandiri Cabang Gorontalo.Jurusan Akuntansi Fakultas Ekonomi dan Bisnis Universitas Negeri Gorontalo, 2013.

Boyd, Harper W. at.all, Marketing Management: A Strategic Approach With Global Orientation. terj Imam Nurmawan. Manajemen Pemasaran: Suatu Pendekatan Strategi dengan Orientasi Global, Edisi II Jilid ii. Jakarta: Erlangga, 2000.
Ghozali, Imam. "Aplikasi Analisis Nultivariate Dengan Program IBM SPSS 21", Cet. VII; Semarang: Badan Penerbit UNDIP, 2013.

Hidayat, Anwar. KepalaUnit Pengadaian SyariahCabang Palu Plaza.

Hafidudin, Didin. dan Hendri Tanjung. Manajemen Pemasaran Syariah dalam Praktik, Jakarta: Gema Insani Impres, 2003.

Hasan, Ali. Marketing,Yogyakarta : Medpress, 2009.

Jasfar, Farida. Manajemen Jasa: Pendekatan terpadu. Bogor: Ghalia Indonesia, 2005.

Kasmir, Costumer Service Excellent: Teori dan Praktik. Cet I; Jakarta: PT. RajaGrafindo, 2017.

Kasmir, Kewirausahaan, Jakarta: PT. RajaGrafindo Persada, 2006.

Kotler, Philip. dan Gery Amstrong. PrinsipPrinsip Pemasaran, Jakarta : Penerbit Erlangga, 2008.

Kotler, Philip. dan Gery Amstrong. PrinsipPrinsip Pemasaran, Jakarta : Penerbit Erlangga, 2001.

Kotler, Philip and Kellerd, Kevin Lane. Marketing managemen. $14^{\text {th }}$ edition. New Jersey:Prentice 2012.

Maulidiya. Analisis Penerapan Segmentasi Pasar pada Produk Tabungan Emas dalam Upaya Menarik Minat Nasabah di Pegadaian Syariah Cabang Blauran Surabaya. Universitas Islam Negeri Sunan Ampel Surabaya, 2017.

Martono, Nanang. Metode Penelitian Kuantitatif, Analisis isi dan Analisis Data Sekunder, Jakarta: PT Raja Grafindo Persada, 2011. 
Martono. Bank dan Lembaga Keuangan Lain. Yogyakarta: EKONISIA, 2004.

Nasusastro, H. Mulyadi. Perilaku Konsumen dalam Perspektif Kewirausahaan, Bandung: Alfabeta, 2012

Nurdin, N., Novia, N., Rahman, A., \& Suhada, R. (2019). Potensi Industri Produk Makanan Halal Di Kota Palu. Jurnal Ilmu Ekonomi dan Bisnis Islam, 1(1), 1-12.

Nurdin, N., \& Yusuf, K. (2020). Knowledge management lifecycle in Islamic bank: the case of syariah banks in Indonesia. International Journal of Knowledge Management Studies, 11(1), 59-80. doi: 10.1504/ijkms.2020.105073

Paputungan, Julianty M. "Akibat Hukum Perubahan Status Perusahaan Umum (Perum) Menjadi Perseroan Terbatas PT. Pegadaian (Persero)', Jurnal, Fakultas Hukum Program Pascasarjana (S2) Universitas Hasanuddin Makassar,Vol III, No. 2, 28 Februari, 2019.

Anwar Hidayat, Kepala Unit Pengadaian Syariah Cabang Palu Plaza "wawancara" di Ups Cabang Palu Plaza 24 Desember 2018

Ruslan, Rosady. Metode Penelitian Public Relations dan Komunikasi. Jakarta: PT Raja Grafindo Persada, 2003.

Sudarsono, Heri. "Bank dan Lembaga Keuangan Syariah "Deskripsi dan Ilustrasi” Yogyakarta:Eikonisia, 2003.

Supriyadi, Ahmad. "Struktur Hukum Pegadaian Syariah Dalam Perspektif Hukum Islam Dan Hukum Positif", Jurnal Penelitian Islam, STAIN Kudus Program Dorktor Pascasarjana IAIN Walisongo Semarang, Vol. III, No.2 Januari-Februari, 2019.
Sastrohadiwiryo, B.Siswanto. Manajemen Tenaga Kerja Indonesia, Jakarta: Sinar Grafika Offset, 2002.

Shihab, M. Quraish. TafsirAl-Misbah: Pesan, Kesan, dan Keserasisan AlQur'an. Vol 3, Ciputat: Lentera hati, 2001.

Sujarweni, Wiratna. Metodologi Penelitian: Lengkap, Praktis, dan Mudah Dipahami, $\quad$ Yogyakarta: Pustakabarupress, 2014.

Sugiono. Metode Penelitian Kuantitatif Kualitatif dan $R \& D$, Bandung: CV Alfabeta, 2009.

Sugiyono. Metode Penelitian Kombinasi, Bandung: CV Alfabeta, 2015.

Sunyoto, Danang. Analisis Regresi dan Uji Hipotesis, Yogyakarta: CAPS.

Sarjono, Haryadi. dan Wilda Julianti. 2011. 'SPSS vs LISREL Sebuah Pengantar : Aplikasi Untuk Riset”, Jakarta: Salemba Empat, 2011.

Tjiptono, Fandi.Pemasaran Jasa, Yogyakarta : Bau Media, 2011.

Widagdo, Herry. Analisis Pengaruh Kualitas Layanan dan Promosi Terhadap Keputusan Konsumen Membeli Komputer Pada PT. XYZ Palembang. Jurnal Ilmiah STIE MDP Vo1. 1 No. 1 September 2011.

Yogiarto, Atanasius Hardian Permana. Pengaruh Bagi Hasil, Promosi, dan Kualitas Pelayanan terhadap Keputusan Penggunaan Jasa Perbankan Syariah Tabungan Mudharabah (Studi Kasus pada Nasabah Bank Muamalat Pekalongan). Diss. Fakultas Ekonomi, 2015. 